\title{
NEW SIRENIAN FINDINGS FROM CRETE ISLAND
}

\author{
Svana K., Iliopoulos G. and Fassoulas C. \\ Natural History Museum of Crete, University of Crete, PO Box 2208, 71409, Irakleio Crete, \\ kaliana22@hotmail.com,gi6@nhmc.uoc.gr,fassoulas@nhmc.uoc.gr
}

\begin{abstract}
In the last five years, the discovery of several new localities of fossil Sirenians found in the Neogene sediments of Crete has increased drastically the number of sirenian localities on the island. Some of the most important findings consist of almost complete post cranial skeletons (localities of Stilos, Panassos near Zaros and Tripitos in Agia Fotia near Siteia). Furthermore, the locality Kotsiana near Chania, where in 1973 Symeonidis and Schultz reported the first sirenian findings from Crete, was revisited and several new sites were recorded. The most recent findings not thoroughly studied yet, are situated in three new fossiliferous sites near Panassos village (Ampelouzos, Panasos 2 and Kefala), and in Afrata at Rodopou peninsula. The preliminary morphological and metrical study of the remains from Panassos and Tripitos, and their comparison with other findings from Crete, as well as with Sirenian material from European localities, has shown that all studied individuals belong to the species Metaxytherium cf. medium (Desmarest 1822). The age of the studied Cretan Sirenian material has been determined as Late Miocene (Tortonian) and the presence of Sirenia in Crete indicates the prevalence of shallow and warm marine environments in coastal areas, rich in sea weeds.
\end{abstract}

Key words: Sirenia, Metaxytherium medium, marine mammals, Late Miocene, Crete.

\section{Introduction}

During the Neogene, Sirenians were abundant shallow water dwellers of the Tethys Ocean. Particularly the genus Metaxytherium (Dugongidae) is considered a very common Dugongid representative found in Miocene or Pliocene sediments across Europe and the Mediterranean basin. Several significant fossiliferous sites with Miocene and Pliocene Sirenian findings in the Mediterranean basin have been documented in Italy, France, Catalonia, Majorca, Hungary, Slovakia, Germany and of course in Crete, which until today is considered as the only region of Greece with documented Sirenian fossil findings (Symeonidis and Schultz, 1973; Markopoulou-Diacantoni, 2001; Markopoulou-Diacantoni and Logos 2004; Kroeger, 2004).

The genus Metaxytherium is a common finding from the European Miocene and Pliocene (Landini et al., 2005), and is generally regarded as the descendent of the Oligocene Halitherium which was identified by the species $H$. schinzii from the Rupelian of Germany, France and Belgium. Domning (1982) presented a phylogenetic analysis and proposed that $M$. krahuletzi and subsequently M. medium, M. serresii and M. subapeninum form an ancestor-descendant sequence (monophyletic clade), although $M$. serresii is clearly smaller than the rest. The reduction in size (dwarfism) of M. serresii is considered an adaptation to the changing environment in the Messinian Mediterranean and more specifically as a consequence of malnourishment due to the reduced diversity, quality and probably quantity of sea 


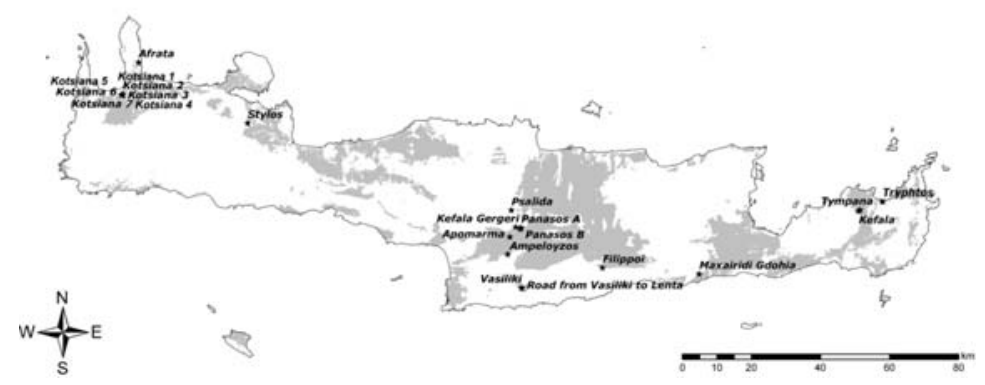

Fig. 1: Map of Crete Island that shows the localities where Sirenian fossil remains have been found todate. The shaded areas indicate the exposures of Neogene rocks on the Island.

grasses and the confined habitats in which the taxon survived during and after the "Messinian salinity crisis" sea (Domning and Thomas, 1987; Bianucci et al., 2004).

The first members of the order Sirenia appeared at the beginning of the Cenozoic at about $50 \mathrm{Ma}$, in the middle Eocene. The order Sirenia (Illiger 1811) is closely related with the group Tethytheria (a group of ungulate, hoofed mammals) that includes the extinct orders Desmostylia and Embrithopoda. The genus Paleoparadoxia is considered to be the ancestral line to all of them.The Sirenians probably were separated from their ancestral group during the Palaeocene (65-54 Ma) and very soon they entered the water fully adapting to aquatic life and dispersed to the New World (Barnes et al., 1985, Domning, 1978, 1999). The order Sirenia contains four families: Prorastomidae, Protosirenidae, Dugongidae and Trichechidae. Today, there are four extant species belonging to the families Dugongidae (Dugong dugong) and Trichechidae (Trichechus manatus, Trichechus inunguis, Trichechus senegalensis) and another species (Steller's cow - Hydrodamalis gigas) that went extinct in the $18^{\text {th }}$ century (Domning, 1988, 1997).

Characteristic Sirenian anatomical features are: the pachyostic bones, the lumbar vertebrae with the very long transverse processes, and the vestigial pelvic bone which is used in sex determination. In addition, the cranium is characterized by a long snout and two distinctive tusks in the front.

Significant Sirenian fossil remains have been found on the island of Crete (Greece) in Late Miocene deposits. A large portion of Crete is covered with Neogene sediments (marls, sands, clays and limestones) most of which are of marine origin, deposited during the Late Miocene from 11.5 Ma and until the Messinian salinity crisis 5 Ma. During the last 30 years, four Late Miocene localities with Sirenian fossil remains have been found on the island of Crete: Kotsiana in Kissamos (Symeonidis and Schultz, 1973), 2 localities, Timpana and Kefala, in the wider area of Sitia (Markopoulou-Diakantoni and Logos, 2004) and also the locality Machairidi near the village Gdochia in Ierapetra (Markopoulou-Diakantoni, 2001) (Fig. 1). In recent years new significant Sirenian findings have been discovered on the island (Svana, 2007). Systematic surveys on the island were performed by the Palaeontology group of the Natural History Museum of Crete, University of Crete (NHMC), which revealed 14 new localities across Crete.

\section{Geographical and palaeoecological settings}

The new localities are the localities of Stylos, Afrata and seven more around the village Kotsiana in western Crete, Panassos, Panassos 2, Ampelouzos and Kefala Gergeri in central Crete, and Tripitos site near Siteia (Fig. 1). In some of the localities the findings consisted of almost complete post-cranial remains. In addition five more new localities have been recently traced on the island by other researchers. These are the localities of Filippoi (Koskeridou, personal communication), Psalida, 
Apomarma, Vassiliki 1 and Vassiliki 2 (Reuter et al., 2005) all of them found in central Crete (Fig. 1). The recovered fossils have been found in sediments belonging to the geological formations of: Roka (Kotsiana sites and Afrata), Akrotiri (Stylos), Ampelouzos (Panassos, Panassos 2, Ampelouzos, Kefala Gergeri), Achladia (Tripitos). All these formations belong to the Late Miocene and more precisely their age is Tortonian (Freudenthal, 1969, Meulenkamp et al., 1979).

In complete contrast to recent shallow marine environments, during the Late Miocene, coral reefs were widely distributed along the Mediterranean region, except from northern regions (Reuter et al., 2006). This biogeographical pattern is generally considered to reflect a warmer than today's climate for the Mediterranean region. During the Late Miocene, in the area of Crete there were multiple periods where extensive regions with shallow warm waters existed, providing favourable conditions for the development of coral reefs. This is also documented by the extensive descriptions of Markopoulou-Diacantoni (2001) for the coral reef system (Porites) in the Ierapetra region and by Reuter's et al. (2005) report for the corals in the basin of Iraklion during the Tortonian.

\section{Material and local geology}

The skeletal elements that have been collected all these years through excavations by NHMC, are basically ribs, cervical, thoracic and lumbar vertebrae and in one case an incisor, the only cranial material found todate. The used reference material for this study belongs to the Palaeontological collection and the Comparative Anatomy collection of the National Museum of Natural History in Paris (MNHN), France and included the species: Metaxytherium medium (Metaxytherium sp., Halianassa cuvieri), Halitherium serresii, Dugon dugong. Also, the two skulls from the Sitia area (localities of Timpana and Kefala) described by Markopoulou-Diakantoni et al. (2004), stored at the Athens Historical Geology and Palaeontology Museum of the University of Athens, were examined.

\subsection{The locality of Stylos}

The studied specimen (Fig. 2) consists of a marly limestone block with embedded Sirenian remains. The specimen was originally found several years ago during the construction of a new road near the village of Stylos (east of Chania), and later the local people placed it in the courtyard of an old church in the village. The material consists of an almost complete and articulated skeleton in the correct anatomical position (Fig. 2). The head and some body parts were secondarily removed and the rest of the remains present considerable weathering. Taphonomical analysis of the skeletal remains shows that after death and due to bloating caused by decay processes, the animal's body was placed at the bottom of the sea in an upside down ventral position, and due to post-burial compression by the sediment burden the ribs were separated into 2 directions. The animal is probably a young individual since the measured skeletal elements have relatively smaller dimensions than the dimensions of the reference material.

\subsection{The locality of Panassos}

The remains were found in an excavation conducted in the outskirts of the village of Panassos, south of Heraklion, in 2002. The material consists of scattered skeletal elements and more specifically of cervical, thoracic and lumbar vertebrae, an incisor and several bone fragments. The bone bearing sediments were shallow deposited marine sandstones that belong to the Ampelouzos formation.

\subsection{The locality of Kotsiana}

Sirenian remains were recently discovered nearby the village Kotsiana, SW of Chania, following a 

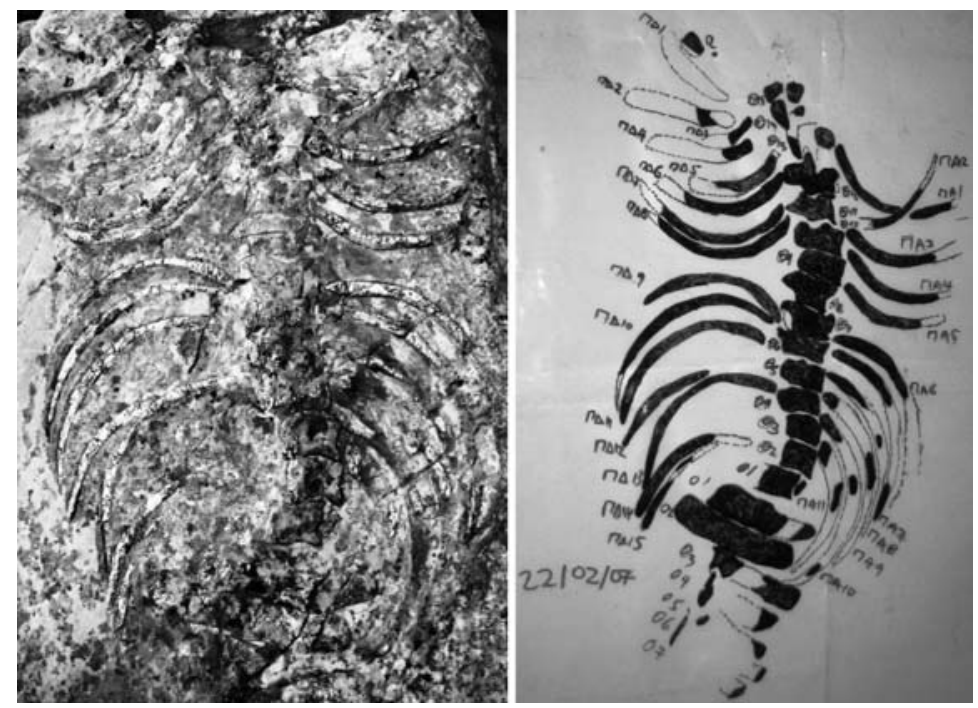

Fig. 2: (left): Photo of the fossil post-cranial skeleton found in the marly limestone block at Stylos; (right): Direct sketch of the skeleton found in Stylos with all present ribs and vertebrae identified and numbered.

previous report by Symeonidis and Schultz (1973). The exact position of the original locality of Symeonidis and Schultz (1973) was traced; nevertheless, since 1973 the described remains (Symeonidis and Schultz, 1973) have been significantly weathered. After surveying the wider area of Kotsiana, the fossiliferous layer that consists of sandy limestones which belong to the Roka formation, was traced and seven more localities with abundant but scattered Sirenian remains were found. Most of them were weathered and fragmentary but some complete specimens have been also found. The collection of various marine invertebrates (bivalves, brachiopods, corals and gastropods) from the same fossiliferous layer, allowed the age determination of the layer as Upper Miocene (Tortonian).

\subsection{The locality of Tripitos in Siteia}

Recently, excavations conducted in deltaic deposits in the locality of Tripitos in Siteia have yielded the remains of an almost complete skeleton that consists of several partly articulated ribs and thoracic vertebrae that seem to belong to an (young) adult. The localities of Timpana and Kefala are found in the wider area of Sitia (Markopoulou-Diakantoni and Logos, 2004). These localities have yielded two important findings, two Sirenian skulls that confirm the species determination and its age (Markopoulou-Diakantoni and Logos, 2004). These remarkable findings lie in the same sedimentary layers that belong to the Achladia formation, as the bone bearing layer from Tripitos.

The material from the other localities, Panassos 2, Ampelouzos, Kefala Gergeri, and Afrata has not been studied yet as the excavations in these localities are still at a preliminary stage, and sufficient financial support has not been available yet.

\section{Systematic palaeontology}

Order: Sirenia (Illiger, 1811) 


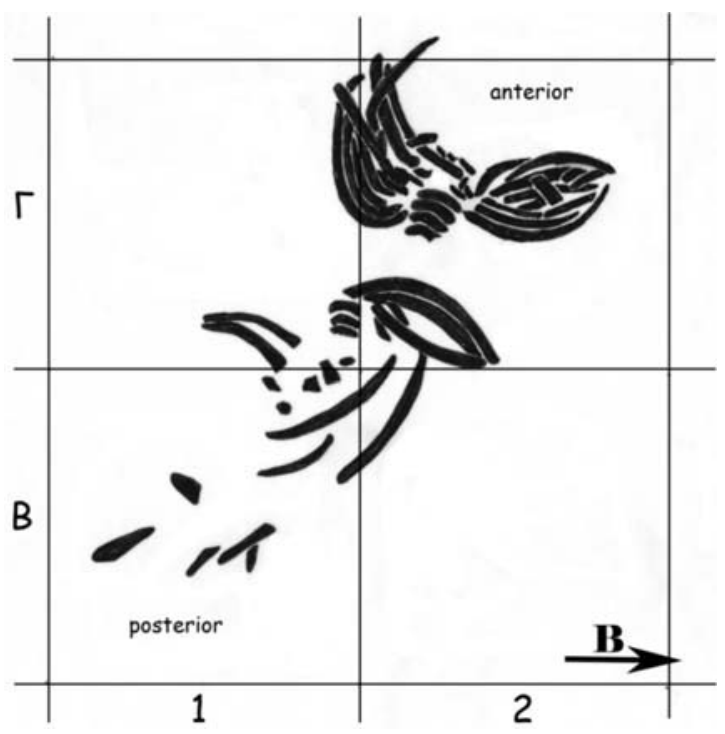

Fig. 3: Actual plan-view of the Sirenian fossil remains from Tripitos. Articulated and associated vertebrae and ribs are clear, indicating that the remains belong to one individual.

Family: Dugongidae (Gray, 1821)

Subfamily: Halitheriinae (Kaup, 1838)

Genus: Metaxytherium (de Christol, 1840)

Species: Metaxytherium medium (Desmarest, 1822) Hoijer, 1952

Synonynms: Metaxytherium cuvieri (de Christol), Markopoulou-Diakantoni and Logos (2004)

Holotype: MNHN Fs 2706, partial left mandible with $\mathrm{M}_{23}$ and roots of $\mathrm{M}_{1}$ (the «Moyen hippopotame» of Cuvier, 1821).

Type Locality: Saint-Michel en Chaisine, Maine-et-Loire, France.

Formation: Calcareous tuff.

Age: Middle to Late Miocene (Serravallian-Tortonian) (Domning, 1996).

Description: The finding of an incisor (tusk) in Panassos locality (Fig. 4 left) is very crucial for the study and the determination of the Sirenian fossil remains, as it can be used as a confirmation of the above species classification. It is an incisor worn a little at the edge of the crown, a fact that along with its size it confers that the individual was an adult. The root of the incisor is transversely elliptical (laterally flattened) and with distinct folding along its length and with a slight curve on the dorsal side. The total length of the incisor is $114.54 \mathrm{~mm}$ and the length of the crown is $15.2 \mathrm{~mm}$, with base dimensions of $11.02 \times 13.10 \mathrm{~mm}$. The ratio of total incisor length to crown length is about 7.5 .

Sirenian vertebrae and ribs present very characteristic morphological features which are clearly present in the fossil findings from all the Cretan localities. Firstly, the typical pachyostosis and osteosclerosis of the Sirenian ribs are evident in the studied material, a feature that has developed in order to facilitate their aquatic mode of life. Moreover, the fairly elongated and thick lateral apophyses of the lumbar vertebrae are further characteristic Sirenian features (Fig. 4 right). 

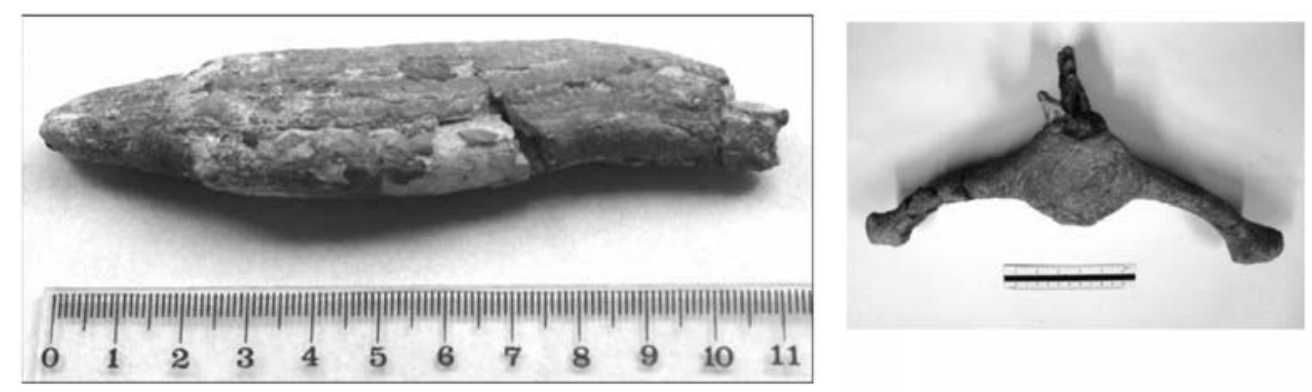

Fig. 4: (left): The incisor tooth found in locality Panassos; (right): A lumbar vertebra with the distinctive long lateral apophyses.

\section{Discussion and Conclusions}

During the Late Miocene, the species M. medium was found in abundance all over (i.e. France, Spain, Italy) the Mediterranean basin and some of the findings are believed to belong to young individuals. Our data seem to verify this statement and are also in accordance with the report of Markopoulou-Diacantoni and Logos (2004) where the two fossil Sirenian skulls found in Timpana and Kefala (Sitia) are identified as Metaxytherium cuvieri de Christol, 1840. In the present study this report is confirmed, nevertheless the species name determination is considered erroneous and therefore it is corrected and synonimased to Metaxytherium cf. medium (Desmarest, 1822) Hoijer, 1952, as this is the valid species name according to the latest accepted Sirenian systematics presented by Domning in 1996. Furthermore, additional evidence for our determinations is the fact that the species M. medium is the only Metaxytherium taxon found in the fossil record of the Mediterranean basin during the Tortonian (Bianucci \& Landini, 2003a, b). As mentioned above, the European (or Mediterranean) Metaxytherium clade of the genus is monophyletic and thus all other species can be excluded with safety. These conclusions support the confirmation of the hypothesis that all Sirenian fossils found in Crete are of Tortonian age and belong to the species Metaxytherium cf. medium.

Extant Sirenia are herbivores and dwell in tropical coastal and river environments where they feed on seagrasses (marine angiorperms). Therefore, the presence of Sirenian remains in several localities all over Crete indicates that during the Tortonian, extensive shallow and warm marine environments, rich in marine angiosperms were common.

In conclusion, it can be said that until today Crete is the only region in Greece, where fossil Sirenian findings have been documented. The reason for this could be assigned to the lack of systematic field work, but also to the fact that probably during the Tortonian in this southern region of the Mediterranean the climate was warmer, facilitating the survival of sea cows. Therefore, it is suggested that in Crete there were extensive regions with warm and shallow waters rich in coral reefs and seagrasses, where of course Sirenians were abundant.

\section{Acknowledgments}

We would like to thank all the people from the Natural History Museum of Crete, University of Crete involved in the conducted excavations. Also special thanks C. Sagne, D. Robineau, C. Lefevre from the MNHN in Paris and to S. Roussiakis from the Athens Historical Geology and Palaeon- 
tology Museum, University of Athens for permission to study and photograph the reference material used in our studies and also to G. Bianucci and S. Sorbi for valuable paper reference material.

\section{References}

Barnes, L.G., Domning, D.P. and Ray, C.E. 1985. Status of studies on fossil marine mammals. Marine Mammal Science 1(1): 15-53.

Bianucci, G., and W. Landini and Varola A. 2003a. New records of Metaxytherium medium (Mammalia:Sirenia) from the Late Miocene of Cisterna quarry (Apulia, southern Italy). Boll. Soc.Pal.Ital. 42 (1-2): 59-63.

Bianucci, G., and Landini, W. 2003b. Metaxytherium medium (Mammalia:Sirenia) from Upper Miocene sediments of the Arenaria di Ponsano Formation (Tuscany, Italy). Riv. Ital. Pal. Stratig. 109 (3): 567-573.

Bianucci, G., G. Carone, D.P. Domning, W. Landini, and L. Rook. 2004. Peri-Messinian dwarfing in Mediterranean Metaxytherium (Mammalia: Sirenia): evidence of habitat degradation related to Mediterranean desiccation? Sedimentary Basins of Libya, 3rd Symposium, Geology of East Libya, November 21-23, 2004, Benghazi, Libya. Abstract.

Domning, D. P. 1978. Sirenia. In: V. J. Maglio and H. B. S. Cooke (eds) Evolution of African Mammals. Cambridge, Mass.: Harvard University Press.

Domning, D.P., 1982. Fossil Sirenia from the Sahabi Formation. Garyounis Scientific Bulletin, Research Center, University of Garyounis, Benghazi, S.P.L.A.J. Special Issue: 29-32.

Domning D. P., Thomas H. 1987. Metaxytherium serresii (Mammalia: Sirenia) from the early Pliocene of Libya and France: A reevaluation of its morphology, phyletic position and biostratigraphic and paleoecological significance. Neogene Paleontology and Geology of the Sahabi, 16, p:205-232.

Domning, D.P 1988. Fossil Sirenia of the west Atlantic and Caribbean region. I. Metaxytherium floridanum Hay, 1922. Journal of Vertebrate Paleontology, 8(4):395-426.

Domning, D. P. 1996. Bibliography and index of the Sirenia and Desmostylia. Smithson. Contrib. Paleobiol. No. 80 : iii +611 .

Domning, D. P. 1997. Fossil Sirenia of the west Atlantic and Caribbean region. VI. Crenatosiren olseni (Reinhart, 1976). Journal of Vertebrate Paleontology, 17 (2): 397-412.

Domning, D. P. 1999. Fossils explained 24: Sirenians (seacows). Geology Today 15(2): 75-79.

Freudenthal, T. 1969. Stratigraphy of Neogene deposits in the Khania province, Crete, the special reference to foraminifera of the family Planobulinidae and the genus Heterostegina. Schotanus \& Jens Inc. Ultrecht - The Netherlands.

Kroeger, K.F. 2004. Sedimentary environments and climate change: a case study (late Miocene, central Crete). PhD thesis, Johannes Gutenberg-Universitat, Mainz.

Landini, W., Bianucci, G., Bisconti, M., Carnevale, G., Sorbini, C., Varola, A. (2005). Il Miocene: I vertebrati marini. In: Bonfiglio, L. (ed.): Paleontologia dei Vertebrati in Italia. Evoluzione biologica, significato ambientale e paleogeografia. Memorie del Museo Civico di Storia Naturale, sezione Scienze della Terra, 6, 145-154.

Markopoulou-Diakantoni A. 2001. Paleoecological observations on the coral refs of the Upper Tortonian between Viannos and Ierapetra provinces (SE Crete). Bulletin of the Geological Society of Greece, vol. XXXIV/2, p.495-502, 2004. Proceedings of the 10th International Congress, Thessaloniki, April 2004.

Markopoulou-Diakantoni A., Logos E. 2004. The occurrence of the Metaxytherium cuvieri Christol in the Late Miocene sediments of Sitia, Crete. Bulletin of the Geological Society of Greece, vol. XXXVI, 2004. Proceedings of the 10th International Congress, Thessaloniki, April 2004.

Meulenkamp, J.E., Dermitzakis, M., Georgiadou-Dikeoulia, E., Jonkers, H.A. \& Boger, H. 1979. Field 
guide to the Neogene of Crete. Publications of the Department of Geology and Palaeontology, University of Athens. Series A, No 32.

Reuter, M., Brachert, T.C., Kroeger, K.F. 2005. Diagenesis of growth bands in fossil scleractinian corals: identification and modes of preservation. Facies. 51: 146-159

Reuter, M., Brachert, T.C., Kroeger, K.F. 2006. Shallow-marine carbonates of the tropical-temperate transition zone: effects of hinterland climate and basin physiography (late Miocene, Crete, Greece) In: Pedley, H.M. \& Carannante, G. (eds). Cool-Water Carbonates: Depositional Systems and Palaeoenvironmental Controls. Geological Society, London, Special Publications, 255, 157-178.

Svana, K. 2007. The Late Miocene Sirenians of Crete. MSc thesis, University of Crete, Heraklion.

Symeonidis, N.K., Schultz O. 1973. Bemerkungen zur neogenen Fischfauna Kretas is und Beschrebung zweier Fundstellen mit miozanen Mollollusken, Echiniiden etc., Insel Kreta, Griechenland. Ann.Naturhistor. Mus.Wien. 77: 141-147. 